\title{
Effects of Hydroxychloroquine on the Human Placenta - Findings from In Vitro Experimental Data and a Systematic Review
}

DOI:

10.1016/j.reprotox.2019.05.056

\section{Document Version}

Accepted author manuscript

Link to publication record in Manchester Research Explorer

Citation for published version (APA):

Scott, R. E., Greenwood, S. L., Hayes, D. J. L., Baker, B. C., Jones, R. L., \& Heazell, A. E. P. (2019). Effects of Hydroxychloroquine on the Human Placenta - Findings from In Vitro Experimental Data and a Systematic Review. Reproductive Toxicology, 87, 50-59. https://doi.org/10.1016/j.reprotox.2019.05.056

\section{Published in:}

Reproductive Toxicology

\section{Citing this paper}

Please note that where the full-text provided on Manchester Research Explorer is the Author Accepted Manuscript or Proof version this may differ from the final Published version. If citing, it is advised that you check and use the publisher's definitive version.

\section{General rights}

Copyright and moral rights for the publications made accessible in the Research Explorer are retained by the authors and/or other copyright owners and it is a condition of accessing publications that users recognise and abide by the legal requirements associated with these rights.

\section{Takedown policy}

If you believe that this document breaches copyright please refer to the University of Manchester's Takedown Procedures [http://man.ac.uk/04Y6Bo] or contact uml.scholarlycommunications@manchester.ac.uk providing relevant details, so we can investigate your claim.

\section{OPEN ACCESS}




\section{Accepted Manuscript}

Title: Effects of Hydroxychloroquine on the Human Placenta

- Findings from In Vitro Experimental Data and a Systematic Review

Authors: Rebecca E. Scott, Susan L. Greenwood, Dexter J.L. Hayes, Bernadette C. Baker, Rebecca L. Jones, Alexander E.P.

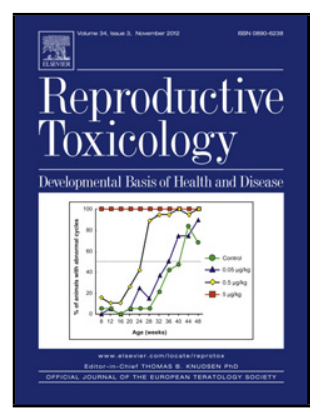
Heazell

PII:

DOI:

Reference:

S0890-6238(19)30023-1 https://doi.org/10.1016/j.reprotox.2019.05.056

To appear in: Reproductive Toxicology

Received date: $\quad 1$ February 2019

Revised date: $\quad 15$ April 2019

Accepted date: $\quad 9$ May 2019

Please cite this article as: Scott RE, Greenwood SL, Hayes DJL, Baker BC, Jones RL, Heazell AEP, Effects of Hydroxychloroquine on the Human Placenta - Findings from In Vitro Experimental Data and a Systematic Review, Reproductive Toxicology (2019), https://doi.org/10.1016/j.reprotox.2019.05.056

This is a PDF file of an unedited manuscript that has been accepted for publication. As a service to our customers we are providing this early version of the manuscript. The manuscript will undergo copyediting, typesetting, and review of the resulting proof before it is published in its final form. Please note that during the production process errors may be discovered which could affect the content, and all legal disclaimers that apply to the journal pertain. 


\section{Effects of Hydroxychloroquine on the Human Placenta - Findings from In Vitro Experimental Data and a Systematic Review}

Authors: Rebecca E Scott, Susan L Greenwood, Dexter JL Hayes, Bernadette C Baker, Rebecca L Jones and Alexander EP Heazell

Affiliation (all authors): Maternal and Fetal Health Research Centre, Faculty of Biology, Medicine and Health, University of Manchester, Manchester Academic Health Science Centre, Manchester M13 9WL

Corresponding Author: Rebecca E Scott; rebecca.scott-5@student.manchester.ac.uk

\section{Highlights}

- Hydroxychloroquine is used in pregnancy for inflammatory conditions.

- Understanding of the effects of hydroxychloroquine on the human placenta is limited.

- Hydroxychloroquine does not have detrimental effects on human placental explants.

- Hydroxychloroquine may attenuate placental inflammation in vitro.

- Further research is needed to determine the placental actions of hydroxychloroquine.

\section{Abstract (149)}

Hydroxychloroquine (HCQ), a toll like receptor (TLR) 7 and 9 antagonist, is used during pregnancy for inflammatory conditions with limited understanding of its placental toxicology. We hypothesized that HCQ does not have toxic effects on the placenta and can modulate cytokine release in response to TLR7/9 activation. A systematic review was conducted and no studies of HCQ on multicellular human placental tissue were identified. Accordingly, placental villous explants were cultured for 7 days with HCQ +/- TLR7/9 agonists. HCQ did not affect cell turnover, nutrient transport or cytokine release but increased IL-10 (anti-inflammatory) secretion and promoted syncytiotrophoblast regeneration. 
Cytokine release stimulated by TLR7/9 agonists was unaffected by HCQ. In conclusion, HCQ did not adversely affect placental tissue and may have a protective anti-inflammatory function. Further research is needed to determine the mechanisms of HCQ actions on human placenta and whether they could be utilized to improve pregnancy outcomes.

\section{Introduction}

Hydroxychloroquine (HCQ) is an antimalarial and immunomodulatory agent.[1] In pregnancy, $\mathrm{HCQ}$ is prescribed for inflammatory conditions associated with adverse perinatal outcomes such as systemic lupus erythematosus (SLE), antiphospholipid syndrome (APS) and placental inflammatory lesions such as chronic histiocytic intervillositis.[2], [3] Despite the use of HCQ in pregnancy, the toxicology and effects of HCQ in human placental tissue has not been determined. Based on established actions in non-placental tissues, HCQ has therapeutic potential to improve placental function in pregnancies associated with heightened inflammation.[4], [5] However, it is yet to be proven whether HCQ produces these potential beneficial effects on human placental tissue. Before considering more widespread use of $\mathrm{HCQ}$, it is important to demonstrate a) that $\mathrm{HCQ}$ does not have adverse effects on human placental tissue, and $b$ ) that HCQ has beneficial effects on inflammatory placental pathologies.

In APS, circulating aPL (antiphospholipid) immune complexes activate dendritic cells and B cells through stimulation of TLR (toll-like receptor) 7 and TLR9, inducing pro-inflammatory cytokine production and disease development.[6] aPL antibodies are also able to increase the expression of TLR7 and TLR9, sensitizing cells to their ligands.[7] Additionally in APS, anti-beta 2 glycoprotein 1 (anti$\beta_{2} \mathrm{GP1}$ ) antibodies form complexes with $\beta 2 \mathrm{GP1}$, which subsequently bind to anionic phospholipids on structures such as platelets and endothelial cells.[8] Subsequently, thrombi form, which cause placental ischaemia and significantly increase the risk of recurrent pregnancy loss.[9] Recent publications also directly implicate the signaling of TLRs in the pathogenesis of pre-eclampsia (PE).[10]-[12] For example, expression of TLR9 is increased in placentas from patients with PE,[13] TLR polymorphisms lower thresholds for early-onset and severe PE [10] and women with established PE have significantly increased maternal plasma concentrations of cell free fetal DNA, an established TLR9 agonist.[14], [15] Furthermore, TLR9 agonism has been implicated as a mechanism for preterm birth and preeclampsia in the mouse[16].

In non-placental tissue HCQ antagonizes toll like receptors TLRs 7 and 9.[4], [5] Although this action is yet to be demonstrated in the placenta, it provides a rationale for considering HCQ as a therapeutic agent to reduce adverse perinatal outcome in maternal and placental inflammatory conditions. HCQ accumulates in intracellular lysosomes where it becomes protonated, increasing the 
intracellular pH.[17] The activation of TLR7 and TLR9 is $\mathrm{pH}$ dependent (pH 4.5-6.5[18]) and in the presence of protonated HCQ, TLR signaling is inhibited. Subsequently, there is a reduction in the production of downstream cytokines and decreased immune cell activation.[16] The human placenta expresses TLR1-TLR10, predominantly in the trophoblast, implicating TLR7 and TLR9 in heightened placental inflammation evident in pregnancy complications.[19] Concordantly, the placental expression of TLR7 and TLR9 provides a potential mode of action for HCQ to reduce raised placental inflammation.

The current study tested the hypothesis that HCQ does not damage placental tissue or compromise function and is able to limit the pro-inflammatory effects of TLR7 and TLR9 agonists. Current knowledge of the effects of HCQ on placenta was collated by performing a systematic literature review and this showed that there are no studies which have investigated effects of HCQ on multicellular preparations of human placental tissue. To better reflect the actions of HCQ in vivo, studies were performed using human placental explants to determine the effects of $\mathrm{HCQ}$, at therapeutically relevant concentrations, on cell turnover, nutrient transport, endocrine function and cytokine secretion. Furthermore, to explore the therapeutic potential of $\mathrm{HCQ}$, we investigated whether HCQ can modulate placental cytokine secretion in response to activation of TLR7 and TLR9.

\section{Materials and Methods}

\subsection{Systematic review}

Literature searches were conducted in Medline, Google Scholar, and Web of Science and were not limited by dates. Reviews were excluded to ensure only original research was included and interpretation bias was limited. Reference lists of included studies were checked for any other relevant papers. All searches were completed by $17^{\text {th }}$ August 2018. A PRISMA-P checklist (2015) was used to guide the review. Data were extracted by two independent researchers (RS, DH). An example search is included in the Supplementary File (Figure 1).

\subsection{Experimental Studies}

The term villous explant model was chosen due to its multicellularity and established ability to provide a functional environment similar to healthy term tissue. This preparation allows studies of cellular turnover that maintains syncytiotrophoblast integrity, nutrient transport, endocrine function and cytokine secretion .[20] Placentas were selected according to the following criteria: maternal age 1840 years, BMI $18.5-30 \mathrm{~kg} / \mathrm{m}^{2}$ and delivery of a singleton fetus between $37-42$ weeks of gestation. 
Ethical approval was obtained (Ref 15/NW0829, Manchester, UK) and written informed consent was provided for all tissue used. Placental villous tissue explants were prepared within 45 minutes of delivery as previously described.[21] Explants were placed into Netwell permeable supports $(74 \mu \mathrm{m}$ mesh; Corning Lifesciences, Amsterdam, The Netherlands) with $1.5 \mathrm{ml}$ of culture medium. [CMRL-1066 $(100 \mathrm{ml} / \mathrm{L}), \mathrm{NaHCO}_{3}(2.2 \mathrm{mg} / \mathrm{ml})$, streptomycin sulphate $(100 \mu \mathrm{g} / \mathrm{ml})$, penicillin $\mathrm{G}(100 \mathrm{IU} / \mathrm{ml})$, insulin $(1 \mu \mathrm{g} / \mathrm{ml})$, retinol acetate $(1 \mu \mathrm{g} / \mathrm{ml})$, l-glutamine $(100 \mu \mathrm{g} / \mathrm{ml})$ and $5 \%$ fetal bovine serum $(\mathrm{pH} 7.2$, Invitrogen Corporation, Paisley, UK)] and maintained at $37^{\circ} \mathrm{C}$ in a humidified incubator in $20 \% \mathrm{O}_{2} / 5 \%$ $\mathrm{CO}_{2}$ for 7 days. Culture medium was changed every 24 hours unless otherwise stated.

In the initial studies, placental villous fragments were treated with therapeutic doses of HCQ (250ng/ml, 750ng/ml and $1.5 \mu \mathrm{g} / \mathrm{ml} \mathrm{ng} / \mathrm{ml}$; Sigma-Aldrich, Dorset, UK) for $48 \mathrm{hrs}$ from day $5(\mathrm{n}=4)$. Doses were chosen based on therapeutic concentrations reported in human serum and cord blood. [22], [23] Culture medium was collected daily for measurement of human chorionic gonadotrophin (hCG) to assess the time course of secretion, a marker of explant endocrine viability in this model.[21] Nutrient transport (taurine uptake) and cellular turnover (apoptosis, proliferation, syncytiotrophoblast integrity) were measured after 7 days of culture.

Subsequent experiments $(n=7)$ were performed using $\mathrm{HCQ}$ at $1.5 \mu \mathrm{g} / \mathrm{ml}$ to determine effects on hormone and cytokine release. To investigate a potentially protective effect of HCQ on cytokines released in response to TLR ligands, explants were treated with $\mathrm{HCQ}(1.5 \mu \mathrm{g} / \mathrm{ml})$ alone or concentrations of Imiquimod (TLR7 agonist; $5 \mu \mathrm{g} / \mathrm{ml}$ in culture medium; InvivoGen, CA, USA) or ODN 2006 (TLR9 agonist; 2.8 $\mu \mathrm{M}$ in culture medium; InvivoGen, CA, USA), alone and in the presence of HCQ. Imiquimod was selected for use as it stimulates TLR 7 at $5 \mu \mathrm{g} / \mathrm{ml}$ [24] whereas ODN 2006, a CpG oligodeoxynucleotide, stimulates TLR 9 at $2.8 \mu \mathrm{M} .[25]$ Treatments were diluted in standard culture medium (composition listed above). Explants were pre-treated with $\mathrm{HCQ}(1.5 \mu \mathrm{g} / \mathrm{ml})$ on day 4 and then treated with agonists + /- HCQ on day 5 for $48 \mathrm{hr}$ (no medium change on day 6 ). Conditioned culture medium was analysed on days 5 and 7 and cellular turnover assessed on day 7 .

\subsection{Cell turnover}

Cell turnover of placental explants was assessed after day 7 of culture by immunohistochemistry for

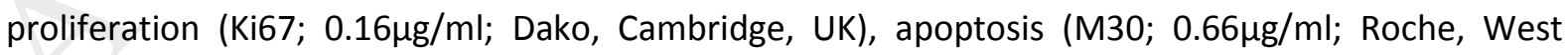
Sussex, UK) and syncytiotrophoblast integrity (cytokeratin 7; $0.9 \mu \mathrm{g} / \mathrm{ml}$; Dako, Cambridge, UK) in methods previously described.[26] Non-immune mouse immunoglobulin $G$ at corresponding concentrations as a negative control and biotinylated goat anti-mouse (1:200 in TBS; Dako, Cambridge, UK) was used as a secondary antibody. Immunostaining was visualized with using an Olympus BX41 
light microscope (Southend-on-Sea, UK) and images were randomly captured using a QIcam Fast 1394 camera (QImaging, Surrey, BC, Canada) and Image Pro Plus 6.0 (Media Cybernetics Inc, Rockville, MD). Two independent observers who were blinded to the identity of the images assessed (a) cytokeratin 7 immunostaining for intactness of the syncytiotrophoblast layer and syncytiotrophoblast regeneration, (b) syncytial nuclear aggregates and (c) stromal vacuolation.

Ki67 and M30 treated sections were analyzed using Histoquest software (Tissue Gnostics, Vienna, Austria). Apoptosis and proliferation were expressed the proportion of positive staining as a percentage of total area of villi and total number of nuclei respectively; data for each experimental condition were normalized to control.

\subsection{Nutrient transport}

The activity of the taurine transporter (TauT) was measured after 7 days of culture as the $\mathrm{Na}^{+}-$ dependent accumulation of ${ }^{3} \mathrm{H}$ taurine into the explants using a previously published method.[27] TauT activity was expressed per mg protein, determined by Bio-Rad protein assay (Bio-Rad Laboratories, Hertfordshire, UK).

\subsection{Analysis of endocrine factors and cytokines}

The inflammatory profile and endocrine function of villous tissue has been shown to vary in high-risk and pro-inflammatory pregnancies[28], [29],[30]. Hormone (hCG, sFIt-1, PIGF, hPL) and cytokine (IL10, IL16, IL1 $\beta$, MCP-1, TNF $\alpha$, INFy) release by the placental villous explants was determined by measuring their concentration in the culture medium using ELISA (hCG, PIGF, hPL; DRG Diagnostics,

Germany, Thermo Fisher Scientific, USA; PIGF and cytokines R\&D Systems, UK). Assays were performed according to the manufacturer's instructions and preliminary experiments conducted to determine the appropriate sample dilution where necessary. Plates were read on a FLUOstar Omega microplate reader ( $450 \pm 10 \mathrm{~nm}$; BMG Labtech, Aylesbury, UK). Endocrine and cytokine secretion was expressed per mg explant protein, determined using a Biorad protein assay (Bio-Rad Laboratories, Hertfordshire, UK) or per mg explant wet weight.

Data are expressed as medians and were analyzed using GraphPad PRISM version 7.0 (San Diego, CA, USA). Differences were considered statistically significant where $P<0.05$. Comparisons between treatment groups were made using a Friedman test. If the Friedman test was significant, a post hoc Dunn's multiple comparisons test was performed. To account for inherent variability in the basal release of placental hormones and cytokines, data were normalized to the control group if the Friedman test was significant. 


\section{Results}

\subsection{Systematic Review}

Eight full text papers which met the inclusion criteria were identified (Figure 1). The findings of included studies are summarized in Table 1. Included studies reported data from human and murine experiments which included rodent models, isolated placental cells and choriocarcinoma cell lines. A further study measured HCQ in human maternal and umbilical cord blood. Importantly, no studies examining the effects in multicellular human placental tissue were identified. No studies reported detrimental effects of $\mathrm{HCQ}$ on placental tissue but $\mathrm{HCQ}$ appears to demonstrate transplacental passage.[31]

\section{Insert Figure 1 here.}

The evidence regarding whether HCQ can limit aPL binding varied; Bertolaccini et al[32] found HCQ did not inhibit aPL binding to mouse tissues, whilst Wu et al[33] and Rand et al[34] reported that HCQ reduced aPL binding to human syncytiotrophoblast and human umbilical vein endothelial cells respectively. In addition, several studies reported that HCQ can limit the impact of aPL-binding on trophoblast fusion, migration and differentiation. Furthermore, HCQ may have a role in preventing placental insufficiency and reducing complement activation in inflammatory conditions.[32]

\begin{tabular}{|c|c|c|c|}
\hline Title & Author/Date & Subject & Key findings \\
\hline $\begin{array}{l}\text { Inhibition of autophagy limits } \\
\text { vertical transmission of Zika virus } \\
\text { in pregnant mice. }\end{array}$ & $\begin{array}{l}\text { Cao et al } \\
(2017)[35]\end{array}$ & $\begin{array}{l}\text { Human trophoblast and } \\
\text { mouse placenta }\end{array}$ & $\begin{array}{l}\text { - Hydroxychloroquine attenuated } \\
\text { placental and fetal ZIKV infection and } \\
\text { ameliorated adverse placental and } \\
\text { fetal outcomes. }\end{array}$ \\
\hline $\begin{array}{l}\text { Complement inhibition by } \\
\text { hydroxychloroquine prevents } \\
\text { placental and fetal brain } \\
\text { abnormalities } \\
\text { antiphospholipid syndrome. }\end{array}$ & $\begin{array}{l}\text { Bertolaccini } \\
\text { et al } \\
(2016)[32]\end{array}$ & $\begin{array}{l}\text { Mouse model of } \\
\text { obstetric APS }\end{array}$ & $\begin{array}{l}\text { - } \mathrm{HCQ} \text { did not inhibit aPL binding to } \\
\text { tissues. } \\
\text { - } \mathrm{HCQ} \text { prevented complement activation } \\
\text { in vivo and in vitro. } \\
\text { - } \quad \text { HCQ prevented placental insufficiency } \\
\text { and abnormal fetal brain development } \\
\text { in APS-mice. }\end{array}$ \\
\hline $\begin{array}{l}\text { Hydroxychloroquine prevents } \\
\text { antiphospholipid antibody- } \\
\text { Induced inhibition of trophoblast } \\
\text { migration }\end{array}$ & $\begin{array}{l}\text { Albert et al } \\
(2015)[36]\end{array}$ & $\begin{array}{l}\text { Human first trimester } \\
\text { trophoblast }\end{array}$ & $\begin{array}{l}\text { - HCQ did not alter aPL-induced } \\
\text { upregulation of trophoblast IL-8, IL-1b, } \\
\text { PIGF, and sEndoglin secretion. } \\
\text { - HCQ partially reversed aPL- induced } \\
\text { inhibition of trophoblast cell migration } \\
\text { and secretion of IL-6. } \\
\text { - HCQ partially prevented aPL-induced } \\
\text { TIMP secretion. }\end{array}$ \\
\hline $\begin{array}{l}\text { Effect of hydroxychloroquine on } \\
\text { antiphospholipid antibody- } \\
\text { induced changes in first } \\
\text { trimester trophoblast function. }\end{array}$ & $\begin{array}{l}\text { Albert et al } \\
(2014)[37]\end{array}$ & $\begin{array}{l}\text { Human first trimester } \\
\text { trophoblast }\end{array}$ & $\begin{array}{l}\text { - HCQ reversed the aPL-inhibition of } \\
\text { trophoblast IL-6 secretion and partially } \\
\text { limited aPL-inhibition of cell migration. } \\
\text { - HCQ did not prevent aPL-induced } \\
\text { TIMP2. }\end{array}$ \\
\hline $\begin{array}{l}\text { Hydroxychloroquine restores } \\
\text { trophoblast fusion affected by } \\
\text { antiphospholipid antibodies }\end{array}$ & $\begin{array}{l}\text { Marchetti et } \\
\text { al (2014)[38] }\end{array}$ & $\begin{array}{l}\text { BeWo and primary } \\
\text { trophoblastic cells }\end{array}$ & $\begin{array}{llr}\text { - } & \text { HCQ restored trophoblastic } \\
\text { differentiation reduced by anti- } \beta 2 G P 1 \\
\text { antibodies. }\end{array}$ \\
\hline
\end{tabular}




\begin{tabular}{|c|c|c|c|}
\hline & & & $\begin{array}{l}\text { - } \mathrm{HCQ} \text { decreased TLR4 mRNA and } \\
\text { protein expression. }\end{array}$ \\
\hline $\begin{array}{lr}\text { Hydroxychloroquine reduces } \\
\text { binding of antiphospholipid } \\
\text { antibodies } \\
\text { syncytiotrophoblasts to } \\
\text { restores annexin A5 expression. }\end{array}$ & $\begin{array}{l}\text { Wu et al } \\
(2011)[33]\end{array}$ & Syncytiotrophoblasts & $\begin{array}{l}\text { - } \mathrm{HCQ} \text { reduced aPL binding to } \\
\text { syncytiotrophoblasts. } \\
\text { - } \mathrm{HCQ} \text { reversed the effects of aPL- } \\
\text { antibodies by reducing } \\
\text { immunoglobulin-G binding and } \\
\text { restoring annexin A5 expression. }\end{array}$ \\
\hline $\begin{array}{l}\text { Hydroxychloroquine protects } \\
\text { the annexin A5 anticoagulant } \\
\text { shield from disruption by } \\
\text { antiphospholipid antibodies: } \\
\text { evidence for a novel effect for an } \\
\text { old antimalarial drug. }\end{array}$ & $\begin{array}{l}\text { Rand et al } \\
(2010)[39]\end{array}$ & $\begin{array}{l}\text { Human umbilical vein } \\
\text { endothelial cells, } \\
\text { trophoblast cells and } \\
\text { APS patient plasma }\end{array}$ & $\begin{array}{ll}\text { - } & \text { HCQ reversed aPL-mediated } \\
\text { disruptions of annexin A5. } \\
\text { - } \quad \text { HCQ reduced binding of aPL antibodies } \\
\text { and normalized plasma coagulation. }\end{array}$ \\
\hline $\begin{array}{l}\text { Evidence of transplacental } \\
\text { passage of hydroxychloroquine } \\
\text { in humans. }\end{array}$ & $\begin{array}{l}\text { Costedoat- } \\
\text { Chalumeau } \\
\text { et al } \\
(2002)[23]\end{array}$ & $\begin{array}{l}\text { Maternal blood and } \\
\text { cord blood }\end{array}$ & $\begin{array}{l}\text { - HCQ concentrations in cord blood were } \\
\text { nearly identical to those found in } \\
\text { maternal blood. }\end{array}$ \\
\hline
\end{tabular}

Table 1. Results of the systematic review. Eight papers were identified which met the search criteria.

\subsection{Experimental Studies}

Four human term placentas were utilized for explant culture in the pilot study examining the concentration-dependent effects of $\mathrm{HCQ}$, and seven further placentas were used in a secondary study examining the potentially protective effects of $\mathrm{HCQ}$ in combination with TLR agonists (demographic details in Supplementary Table 1). Although underpowered, no obvious qualitative trends that would indicate differences between fetal sex were observed.

\subsubsection{Concentration dependent effects of hydroxychloroquine on explant integrity and function}

$\mathrm{HCQ}$, at any of the concentrations applied, did not affect apoptosis, proliferation or syncytiotrophoblast integrity in term placental villous explants (Figure 2; $p>0.05 ; n=7$ ).

Insert Figure 2 here. 
Examples of immunostaining for proliferation, apoptosis and STB integrity are shown (Figure 3 A-F) for explants maintained in control medium and medium with $1.5 \mu \mathrm{g} / \mathrm{ml} \mathrm{HCQ}$. hCG secretion by villous explants in culture for 7 days followed the temporal profile previously published [40] (Figure 3G). Taurine transporter (TauT) activity (fmol/mg protein) increased over time (Figure $3 \mathrm{H}$ ). However, there was no significance difference in the rate of increase between treatments. At 90mins, TauT activity was not altered by hydroxychloroquine treatment $(p>0.05 ; n=4)$.

Insert Figure 3 here.

\subsubsection{Effect of HCQ and TLR agonists on cell turnover}

Examples of immunostaining for proliferation, apoptosis and STB integrity are shown for explants maintained in control medium, medium with $1.5 \mu \mathrm{g} / \mathrm{ml} \mathrm{HCQ}$, Imiquimod $(5 \mu \mathrm{g} / \mathrm{ml})$ or ODN 2006 $(2.8 \mu \mathrm{M})$ (Figure $4 \mathrm{~A}-\mathrm{L})$. In agreement with the findings of the pilot study, treatment with $1.5 \mu \mathrm{g} / \mathrm{ml} \mathrm{HCQ}$ for $72 \mathrm{hrs}$ did not affect proliferation compared to control (Figure $4 \mathrm{M} ; \mathrm{p}>0.05$, Wilcoxon Signed Rank Test; $n=7)$. A slight increase in proliferation was seen with ODN 2006, but only ODN 2006 treatment in combination with HCQ significantly elevated proliferation compared to control $(p=0.04$; Wilcoxon Signed Rank Test). In agreement with the pilot data, treatment with $1.5 \mu \mathrm{g} / \mathrm{ml} \mathrm{HCQ}$ for $72 \mathrm{hrs} \mathrm{did} \mathrm{not}$ affect apoptosis compared to control (Figure 4N). Both Imiquimod and ODN 2006 significantly increased apoptosis compared to control when applied alone (Figure $4 \mathrm{~N} ; \mathrm{p}=0.03$ ); but not when applied in combination with HCQ.

HCQ treatment significantly decreased the number of villi with a vacuolated stroma (Fig $40 ; p=0.03$, Wilcoxon Signed Rank Test; $n=7$ ). Compared to control, HCQ and ODN 2006 plus HCQ treated explants had a significantly increased proportion of villi with an intact syncytiotrophoblast layer (Figure 4P; $p=0.03$ and $p=0.02$ respectively). ODN 2006, both with and without HCQ significantly increased the percentage of villi with a regenerating syncytiotrophoblast layer (Supplementary File Figure2, $p=0.04$ and $\mathrm{p}=0.01$ respectively).

Insert Figure 4 here. 


\subsubsection{Effect of HCQ and TLR agonists on endocrine and cytokine secretion}

Treatment with HCQ $(1.5 \mu \mathrm{g} / \mathrm{ml})$ for $24 \mathrm{hrs}$ did not alter release of hCG, sFlt-1, PIGF or hPL (Figure 5AD). Following $24 \mathrm{hrs}$ of $\mathrm{HCQ}$ exposure, IL-10 secretion was increased compared to untreated groups (Figure 5E; $p=0.02$, Wilcoxon matched-pairs signed rank test; day 5 of explant culture). Exposure of villous explants to HCQ did not alter secretions of IL-1 $\beta$, TNF $\alpha$, IL-6 or MCP-1 (Figure 5E; $p>0.05$, Wilcoxon matched-pairs signed rank test).

Insert Figure 5 here.

As seen in the experimental studies and after $24 \mathrm{hrs}$ of treatment, $\mathrm{HCQ}$ treatment for 72 hours did not change hCG secretion compared to control (Figure 6A). ODN 2006 significantly increased hCG secretion compared to control $(p=0.026)$. This effect was not seen when ODN 2006 treatment was combined with $\mathrm{HCQ}$.

After $72 \mathrm{hrs}$ of HCQ treatment, a small but significant decrease in $\mathrm{hPL}$ release was seen when compared to control (Figure 6B, $p=0.03 ; n=7$ ). hPL release was also reduced following Imiquimod, HCQ plus Imiquimod and HCQ plus ODN 2006 treatments ( $p<0.05$ ). ODN 2006, both with and without HCQ, increased release of sFlt-1 (Figure 6C). ODN 2006 treatment decreased secretion of PIGF (Figure 6D, $\mathrm{p}=0.03)$. The sFlt-1/PIGF ratio was unaffected by lone HCQ treatment; only ODN 2006 and ODN 2006 with $\mathrm{HCQ}$, significantly increased this (Figure $6 \mathrm{E}, \mathrm{p}=0.02$ and 0.03 respectively). $\mathrm{HCQ}$ was unable to attenuate the ODN 2006-induced increase in the sFlt-1/PIGF ratio or ODN 2006-induced and Imiquimod-induced reductions in hPL release.

IL-6 release was increased in the ODN 2006 plus HCQ ( $p=0.03$, Wilcoxon Signed Rank Test; n=7) and Imiquimod plus HCQ ( $p=0.02)$ treatment groups, but not in the lone agonist or lone HCQ treatment groups (Figure 6F). ODN $2006(2.8 \mu \mathrm{M})$ caused a significant increase in the release of MCP-1 ( $p=0.04)$, but this was attenuated in the presence of $\mathrm{HCQ}(1.5 \mu \mathrm{g} / \mathrm{ml})$ (Figure $6 \mathrm{G})$. Imiquimod $(5 \mu \mathrm{g} / \mathrm{ml}$ ) treatment for $72 \mathrm{hrs}$ increased release of IL-1 $\beta$ in villous explants (Figure $6 \mathrm{H}, \mathrm{p}=0.04$ ), but in combination with HCQ $(1.5 \mu \mathrm{g} / \mathrm{ml})$ caused a significant increase in IL-10, IL-6 and IL-1B. ODN $2006(2.8 \mu \mathrm{M})$ suppressed release of anti-inflammatory IL-10 ( $p=0.03)$, but this suppression was not seen in the presence of ODN $2006(2.8 \mu \mathrm{M})$ and HCQ $(1.5 \mu \mathrm{g} / \mathrm{ml})$ (Figure 6I). IFN-y was not detected in the culture medium of any explant culture.

Insert Figure 6 here. 


\section{Discussion}

HCQ is currently used in human pregnancy, even though it is not formally recognised for safe obstetric use.[41] HCQ crosses the placenta[31] but exposure in pregnancy does not appear to be associated with developmental toxicity. [41] A systematic review and meta-analysis by Kaplan et al[42] found that antenatal use of HCQ does not appear to increase the risk of adverse pregnancy outcomes, except spontaneous abortion rates, which may be related to underlying autoimmune activity. Our systematic review identified limited understanding of the safety and direct effects of HCQ in human placental tissue. Although no detrimental effects of HCQ on placental cells were identified, no previous research utilized a multicellular human placenta model. The subsequent experimental data addressed the research gaps established by the systematic review; the effects of HCQ on placental function, structure and nutrient transport were examined in term villous explants. To further explore the therapeutic potential of $\mathrm{HCQ}$, we investigated whether HCQ can modulate placental cytokine secretion in response to activation of TLR7 and TLR9.

The current study demonstrated that $\mathrm{HCQ}$, at levels reported in the serum of women receiving treatment for APS,[22] had no detrimental effects on placental integrity as assessed by cellular turnover, taurine transporter activity and hCG secretion in vitro. At $1.5 \mu \mathrm{g} / \mathrm{ml}$, the highest clinically relevant concentration, HCQ had potentially beneficial effects by significantly increasing the secretion of anti-inflammatory cytokine IL-10 after $24 \mathrm{hrs}$, increasing the proportion of villi with intact STB and reducing the number of villi with vacuolated stroma in explant culture after $72 \mathrm{hrs}$. HCQ did not affect the sFlt-1/PIGF ratio; a marker of pre-eclampsia.[43] However, a small but significant reduction in hPL release by HCQ was observed after $72 \mathrm{hrs}$; as $\mathrm{hPL}$ is essential for a healthy pregnancy, this finding warrants further investigation.

Human IL-10 is a cytokine produced by CD4+ T cell clones, B cells and monocytes[44] and is believed to play an important role in the placenta inducing maternal tolerance of the allogeneic fetus.[44], [45] Moreau et al. (1999) proposed that IL-10 achieves this by altering the HLA class I expression pattern at the maternal-fetal barrier, thereby protecting the fetus from rejection.[46] Thus, HCQ-induced upregulation of IL-10 may explain the increased rates of live births seen following HCQ treatment in women with APS.[47]

In addition to increasing the release of IL-10, treatment with $1.5 \mu \mathrm{g} / \mathrm{ml} \mathrm{HCQ}$ significantly increased the number of villi with intact syncytiotrophoblast at day 7 of explant culture, consistent with improving regeneration of this critical cell layer. HCQ also significantly reduced the number of villi with vacuolated stroma; smaller numbers of stromal vacuoles are associated with improved 
transplacental transport and exchange.[48] Thus, these structural changes could potentially lead to improved placental function.

To explore the therapeutic potential of $\mathrm{HCQ}$, we investigated whether $\mathrm{HCQ}$ can modulate placental cytokine secretion in response to activation of TLR7 and TLR9. Despite demonstrating potentially beneficial effects in normal tissue, HCQ was unable to significantly attenuate the proinflammatory effects of TLR7 and TLR9 agonists in this in vitro model. A statistically beneficial effect may be seen in pathological tissues from women with pre-eclampsia,[49] APS [6] or inflammatory placenta lesions[50], [51], where overstimulation of TLR7 and TLR9 has been implicated. Additionally, sexual dimorphism has been observed in response to inflammatory insults so further work investigating the anti-inflammatory effects of HCQ should stratify for fetal sex. Experiments in nonplacental tissues have demonstrated that HCQ antagonizes TLRs 7 and 9,[4], [5] but the downstream effects of this mechanism were not witnessed in the current study. Further studies examining the mechanism of HCQ in pathological human placental tissues are required but a co-culture model involving placental and immune cells may be the best model in which to identify the cells implicated.[52]

Many women with SLE take HCQ to manage the autoimmune and inflammatory aspects of their disease. Severe and more frequent SLE flares have been witnessed following HCQ discontinuation in pregnancy.[2] As SLE flares are strongly associated with pregnancy loss, [53] data from the current study and the systematic review supports the recommendation that HCQ treatment should be maintained throughout pregnancy in patients with SLE as HCQ had no deleterious direct effects on placental tissue.[2] However, the current study did not examine placental factors such as oxidative stress and vascular reactivity, so caution should still be taken when prescribing HCQ in pregnancy. Further research investigating the effects of $\mathrm{HCQ}$ on angiogenic factors such as VEGF and integrins is recommended. Furthermore, $\mathrm{HCQ}$ is a chiral drug which is metabolized to three active metabolites: monodesethylhydroxychloroquine, desethylchloroquine and bisdesethylchloroquine. [54] As HCQ metabolism is known to vary between patients, each metabolite should be directly investigated for placental and developmental toxicity.[55] HCQ treatment should only been offered as a complementary therapy in APS until the results from the HYPATIA study, a multinational randomized controlled trial of HCQ versus placebo, are published.[56]

\section{Conclusion}

Despite the use of HCQ in maternal medical conditions and more recently for inflammatory conditions of the placenta, understanding of the effects of HCQ on the human placenta is limited. Importantly, 
our systematic review and experimental studies demonstrates that HCQ has no detrimental effects on placental cell turnover, nutrient transport, endocrine function or cytokine secretion. Furthermore, HCQ increased secretion of anti-inflammatory cytokine IL-10, promoted the regeneration of the syncytiotrophoblast and reduced vacuolation in term placental tissue, indicating that HCQ treatment may have beneficial effects in inflammatory placental diseases. However, the current study failed to demonstrate that HCQ has protective effects against the stimulation of TLRs. HCQ may improve pregnancy outcomes and provide protective affects through alternative mechanisms, such as inhibiting complement activation[32] or reversing the effects of free fetal haemoglobin on fetoplacental vessels.[57] Further research is needed to determine the safety and mechanism of action of HCQ in placental tissue and how this could be best utilised to potentially improve pregnancy outcomes.

\section{Funding}

This study was funded by Tommy's, UK. Rebecca Scott is supported by the Octavia's Trust Bursary.

\section{Acknowledgements}

We would like to thank the staff of the Maternal and Fetal Health Research Centre at the University of Manchester for their assistance with this project 


\section{References}

[1] I. Ben-Zvi, S. Kivity, P. Langevitz, and Y. Shoenfeld, "Hydroxychloroquine: From Malaria to Autoimmunity," Clin. Rev. Allergy Immunol., vol. 42, no. 2, pp. 145-153, Apr. 2012.

[2] J. Wan, S. Imadojemu, and V. P. Werth, "Management of rheumatic and autoimmune blistering disease in pregnancy and postpartum," Clin. Dermatol., vol. 34, no. 3, pp. 344-352, 2016.

[3] A. Mekinian et al., "Chronic histiocytic intervillositis: Outcome, associated diseases and treatment in a multicenter prospective study," Autoimmunity, vol. 48, no. 1, pp. 40-45, Jan. 2015.

[4] M. Lamphier et al., "Novel Small Molecule Inhibitors of TLR7 and TLR9: Mechanism of Action and Efficacy In Vivo," Mol. Pharmacol., vol. 85, no. 3, 2014.

[5] A. Kužnik, M. Benčina, U. Švajger, M. Jeras, B. Rozman, and R. Jerala, "Mechanism of Endosomal TLR Inhibition by Antimalarial Drugs and Imidazoquinolines," J. Immunol., vol. 186, no. 8, 2011.

[6] F. J. Barrat and R. L. Coffman, "Development of TLR inhibitors for the treatment of autoimmune diseases," Immunol. Rev., vol. 223, no. 1, pp. 271-283, Jun. 2008.

[7] N. Prinz et al., "Antiphospholipid antibodies induce translocation of TLR7 and TLR8 to the endosome in human monocytes and plasmacytoid dendritic cells," Blood, vol. 118, no. 8, 2011.

[8] J. Arnout, "The role of beta 2-glycoprotein I-dependent lupus anticoagulants in the pathogenesis of the antiphospholipid syndrome.," Verh. K. Acad. Geneeskd. Belg., vol. 62, no. 5, pp. 353-72, 2000.

[9] Y. Ho, K. Ahuja, H. Körner, and M. Adams, "ß2GP1, Anti-ß2GP1 Antibodies and Platelets: Key Players in the Antiphospholipid Syndrome," Antibodies, vol. 5, no. 2, p. 12, May 2016.

[10] F. Xie, S. E. Turvey, M. A. Williams, G. Mor, and P. Von Dadelszen, "REVIEW ARTICLE: Toll-Like Receptor Signaling and Pre-Eclampsia," Am. J. Reprod. Immunol., vol. 63, no. 1, pp. 7-16, Dec. 2009.

[11] Y. M. Kim et al., "Toll-like receptor 4: A potential link between 'danger signals,' the innate immune system, and preeclampsia?," Am. J. Obstet. Gynecol., vol. 193, no. 3, p. 921.e1-921.e8, Sep. 2005.

[12] C. Mazouni et al., "Preeclampsia: Impaired inflammatory response mediated by Toll-like receptors," J. Reprod. Immunol., vol. 78, no. 1, pp. 80-83, Jun. 2008.

[13] A. Pineda, S. L. Verdin-Terán, A. Camacho, and L. Moreno-Fierros, "Expression of Toll-like Receptor TLR-2, TLR-3, TLR-4 and TLR-9 Is Increased in Placentas from Patients with 
Preeclampsia," Arch. Med. Res., vol. 42, no. 5, pp. 382-391, Jul. 2011.

[14] D. L. Rolnik, N. O'Gorman, M. Fiolna, D. van den Boom, K. H. Nicolaides, and L. C. Poon, "Maternal plasma cell-free DNA in the prediction of pre-eclampsia," Ultrasound Obstet. Gynecol., vol. 45, no. 1, pp. 106-111, Jan. 2015.

[15] E. A. L. Enninga, W. K. Nevala, S. G. Holtan, and S. N. Markovic, "Immune Reactivation by CellFree Fetal DNA in Healthy Pregnancies Re-Purposed to Target Tumors: Novel Checkpoint Inhibition in Cancer Therapeutics," Front. Immunol., vol. 6, p. 424, Aug. 2015.

[16] A. Scharfe-Nugent et al., "TLR9 Provokes Inflammation in Response to Fetal DNA: Mechanism for Fetal Loss in Preterm Birth and Preeclampsia," J. Immunol., vol. 188, no. 11, pp. 5706-5712, Jun. 2012.

[17] A. M. Kaufmann and J. P. Krise, "Lysosomal Sequestration of Amine-Containing Drugs: Analysis and Therapeutic Implications," J. Pharm. Sci., vol. 96, no. 4, pp. 729-746, 2007.

[18] I. Mellman, R. Fuchs, and A. Helenius, "Acidification of the Endocytic and Exocytic Pathways," Annu. Rev. Biochem., vol. 55, no. 1, pp. 663-700, Jun. 1986.

[19] K. Koga, P. B. Aldo, and G. Mor, "Toll-like receptors and pregnancy: Trophoblast as modulators of the immune response," J. Obstet. Gynaecol. Res., vol. 35, no. 2, pp. 191-202, Apr. 2009.

[20] R. K. Miller, O. Genbacev, M. A. Turner, J. D. Aplin, I. Caniggia, and B. Huppertz, "Human placental explants in culture: Approaches and assessments," Placenta, vol. 26, no. 6, pp. 439448, Jul. 2005.

[21] C. M. Simán, C. P. Sibley, C. J. P. Jones, M. A. Turner, and S. L. Greenwood, "The functional regeneration of syncytiotrophoblast in cultured explants of term placenta," Am. J. Physiol. Regul. Integr. Comp. Physiol., vol. 280, no. 4, 2001.

[22] C. C. Mok, H. J. Penn, K. L. Chan, S. M. Tse, L. J. Langman, and P. J. Jannetto, "Hydroxychloroquine Serum Concentrations and Flares of Systemic Lupus Erythematosus: A Longitudinal Cohort Analysis," Arthritis Care Res. (Hoboken)., vol. 68, no. 9, pp. 1295-1302, Sep. 2016.

[23] N. Costedoat-Chalumeau et al., "Evidence of transplacental passage of hydroxychloroquine in humans.," Arthritis Rheum., vol. 46, no. 4, pp. 1123-4, Apr. 2002.

[24] R. Fishelevich et al., "Imiquimod-induced TLR7 signaling enhances repair of DNA damage induced by ultraviolet light in bone marrow-derived cells.," J. Immunol., vol. 187, no. 4, pp. 1664-73, Aug. 2011. 
[25] Y. C. Kim et al., "Oligodeoxynucleotides stabilize Helios-expressing Foxp3+ human T regulatory cells during in vitro expansion," Blood, vol. 119, no. 12, 2012.

[26] L. K. Warrander et al., "Maternal Perception of Reduced Fetal Movements Is Associated with Altered Placental Structure and Function," PLoS One, vol. 7, no. 4, p. e34851, Apr. 2012.

[27] S. L. Greenwood and C. P. Sibley, "In vitro methods for studying human placental amino acid transport placental villous fragments.," Methods Mol. Med., vol. 122, pp. 253-264, 2006.

[28] S. Girard et al., "Circulating cytokines and alarmins associated with placental inflammation in high-risk pregnancies.," Am. J. Reprod. Immunol., vol. 72, no. 4, pp. 422-34, Oct. 2014.

[29] H. Derricott, R. L. Jones, S. L. Greenwood, G. Batra, M. J. Evans, and A. E. P. Heazell, "Characterizing Villitis of Unknown Etiology and Inflammation in Stillbirth," Am. J. Pathol., vol. 186, no. 4, pp. 952-961, Apr. 2016.

[30] L. E. Higgins et al., "Placental Features of Late-Onset Adverse Pregnancy Outcome.," PLoS One, vol. 10, no. 6, p. e0129117, 2015.

[31] N. Costedoat-Chalumeau et al., "Evidence of transplacental passage of hydroxychloroquine in humans," Arthritis Rheum., vol. 46, no. 4, pp. 1123-1124, Apr. 2002.

[32] M. L. Bertolaccini et al., "Complement inhibition by hydroxychloroquine prevents placental and fetal brain abnormalities in antiphospholipid syndrome.," J. Autoimmun., vol. 75, pp. 30-38, Dec. 2016.

[33] X.-X. Wu, S. Guller, and J. H. Rand, "Hydroxychloroquine reduces binding of antiphospholipid antibodies to syncytiotrophoblasts and restores annexin A5 expression," Am. J. Obstet. Gynecol., vol. 205, no. 6, p. 576.e7-576.e14, Dec. 2011.

[34] J. H. Rand et al., "1. Rand JH, Wu X-X, Quinn AS, et al. Hydroxychloroquine protects the annexin A5 anticoagulant shield from disruption by antiphospholipid antibodies: evidence for a novel effect for an old antimalarial drug. Blood. 2010;115(11):2292-2299. doi:10.1182/blood," Blood, vol. 115, no. 11, pp. 2292-2299, Mar. 2010.

[35] B. Cao, L. A. Parnell, M. S. Diamond, and I. U. Mysorekar, "Inhibition of autophagy limits vertical transmission of Zika virus in pregnant mice.," J. Exp. Med., vol. 214, no. 8, pp. 2303-2313, Aug. 2017.

[36] C. Albert, "Hydroxychloroquine Prevents Antiphospholipid Antibody-Induced Inhibition Of Trophoblast Migration," Yale Med. Thesis Digit. Libr., Jan. 2015.

[37] C. R. Albert et al., "Effect of hydroxychloroquine on antiphospholipid antibody-induced 
changes in first trimester trophoblast function.," Am. J. Reprod. Immunol., vol. 71, no. 2, pp. 154-164, Feb. 2014.

[38] T. Marchetti, A. Ruffatti, C. Wuillemin, P. de Moerloose, and M. Cohen, "Hydroxychloroquine restores trophoblast fusion affected by antiphospholipid antibodies.," J. Thromb. Haemost., vol. 12, no. 6, pp. 910-920, Jun. 2014.

[39] J. H. Rand et al., "Hydroxychloroquine protects the annexin A5 anticoagulant shield from disruption by antiphospholipid antibodies: evidence for a novel effect for an old antimalarial drug," Blood, vol. 115, no. 11, pp. 2292-2299, Mar. 2010.

[40] C. M. Simán, C. P. Sibley, C. J. Jones, M. A. Turner, and S. L. Greenwood, "The functional regeneration of syncytiotrophoblast in cultured explants of term placenta.," Am. J. Physiol. Regul. Integr. Comp. Physiol., vol. 280, no. 4, pp. R1116-22, Apr. 2001.

[41] C. Abarientos, K. Sperber, D. L. Shapiro, W. S. Aronow, C. P. Chao, and J. Y. Ash, "Hydroxychloroquine in systemic lupus erythematosus and rheumatoid arthritis and its safety in pregnancy," Expert Opin. Drug Saf., vol. 10, no. 5, pp. 705-714, Sep. 2011.

[42] Y. C. Kaplan, J. Ozsarfati, C. Nickel, and G. Koren, "Reproductive outcomes following hydroxychloroquine use for autoimmune diseases: a systematic review and meta-analysis," Br. J. Clin. Pharmacol., vol. 81, no. 5, pp. 835-848, May 2016.

[43] H. Zeisler et al., "Predictive Value of the sFlt-1:PIGF Ratio in Women with Suspected Preeclampsia," N. Engl. J. Med., vol. 374, no. 1, pp. 13-22, Jan. 2016.

[44] I. Roth, D. B. Corry, R. M. Locksley, J. S. Abrams, M. J. Litton, and S. J. Fisher, "Human placental cytotrophoblasts produce the immunosuppressive cytokine interleukin 10.," J. Exp. Med., vol. 184, no. 2, pp. 539-48, Aug. 1996.

[45] P. Cadet, P. L. Rady, S. K. Tyring, R. B. Yandell, and T. K. Hughes, "Interleukin-10 messenger ribonucleic acid in human placenta: implications of a role for interleukin-10 in fetal allograft protection.," Am. J. Obstet. Gynecol., vol. 173, no. 1, pp. 25-9, Jul. 1995.

[46] P. Moreau et al., "IL-10 selectively induces HLA-G expression in human trophoblasts and monocytes.," Int. Immunol., vol. 11, no. 5, pp. 803-11, May 1999.

[47] S. Sciascia et al., "The efficacy of hydroxychloroquine in altering pregnancy outcome in women with antiphospholipid antibodies. Evidence and clinical judgment.," Thromb. Haemost., vol. 115, no. 2, pp. 285-90, Jan. 2016.

[48] Q. Meng et al., "Ultrastructure of Placenta of Gravidas with Gestational Diabetes Mellitus.," 
Obstet. Gynecol. Int., vol. 2015, p. 283124, 2015.

[49] P. Chatterjee et al., "Placental Toll-Like Receptor 3 and Toll-Like Receptor 7/8 Activation Contributes to Preeclampsia in Humans and Mice," PLoS One, vol. 7, no. 7, p. e41884, Jul. 2012.

[50] K. Hussein, A. Stucki-Koch, H. Kreipe, and H. Feist, "Expression of Toll-Like Receptors in Chronic Histiocytic Intervillositis of the Placenta," Fetal Pediatr. Pathol., vol. 34, no. 6, pp. 407-412, Nov. 2015.

[51] H. N. Simhan, T. MacPherson, S. N. Caritis, and M. A. Krohn, "Maternal and fetal Toll-like receptor 4 genotype and chorionic plate inflammatory lesions," Am. J. Obstet. Gynecol., vol. 199, no. 4, p. 400.e1-400.e4, Oct. 2008.

[52] H. Derricott, A. E. P. Heazell, S. L. Greenwood, and R. L. Jones, "A novel in vitro model of villitis of unknown etiology demonstrates altered placental hormone and cytokine profile," Am. J. Reprod. Immunol., p. e12725, Jul. 2017.

[53] M. Rezk, H. Ellakwa, A. Al-Halaby, A. Shaheen, A. Zahran, and H. Badr, "Predictors of poor obstetric outcome in women with systemic lupus erythematosus: a 10-year experience of a university hospital," J. Matern. Neonatal Med., vol. 30, no. 17, pp. 2031-2035, Sep. 2017.

[54] M. Soichot et al., "Development, validation and clinical application of a LC-MS/MS method for the simultaneous quantification of hydroxychloroquine and its active metabolites in human whole blood," J. Pharm. Biomed. Anal., vol. 100, pp. 131-137, Nov. 2014.

[55] J. Yeon Lee, J. Lee, S. Ki Kwok, J. Hyeon Ju, K. Su Park, and S.-H. Park, "Factors Related to Blood Hydroxychloroquine Concentration in Patients With Systemic Lupus Erythematosus," Arthritis Care Res. (Hoboken)., vol. 69, no. 4, pp. 536-542, Apr. 2017.

[56] K. Schreiber et al., "HYdroxychloroquine to Improve Pregnancy Outcome in Women with AnTIphospholipid Antibodies (HYPATIA) Protocol: A Multinational Randomized Controlled Trial of Hydroxychloroquine versus Placebo in Addition to Standard Treatment in Pregnant Women with Antiphospholipid Syndrome or Antibodies," Semin. Thromb. Hemost., Jun. 2017.

[57] A. Brook, K. Francis, S. R. Hansson, I. P. Crocker, and P. Brownbill, "Hydroxychloroquine ameliorates FGR-associated free fetal haemoglobin evoked fetoplacental vasoconstriction," Placenta, vol. 57, pp. 314-315, Sep. 2017. 


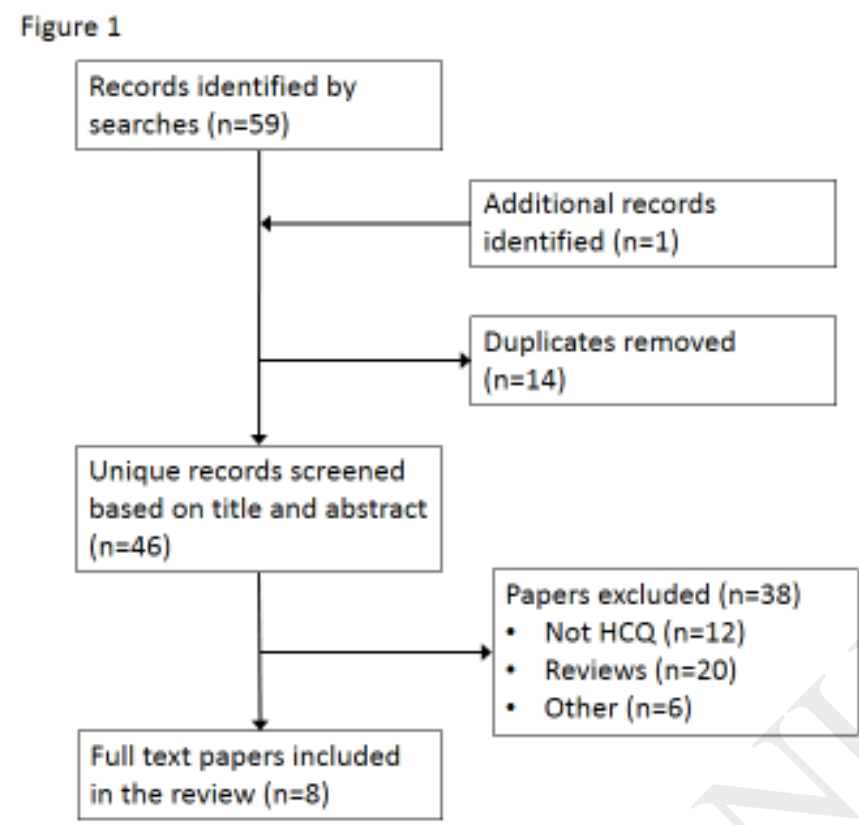

Figure 1. PRISMA flow chart of the systematic review of published studies investigating the effects of HCQ on human placental tissue. 59 records were identified by the initial search strategy, which were then independently screened by two researchers. Eight papers met the search criteria. 
A.

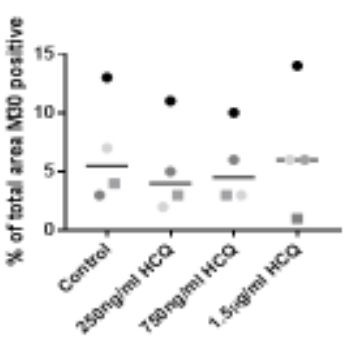

c.

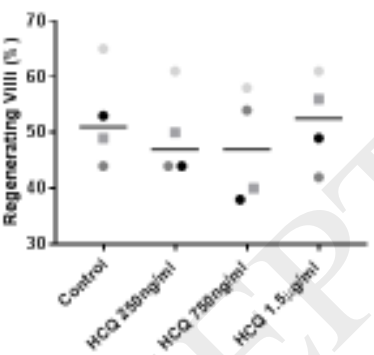

B.

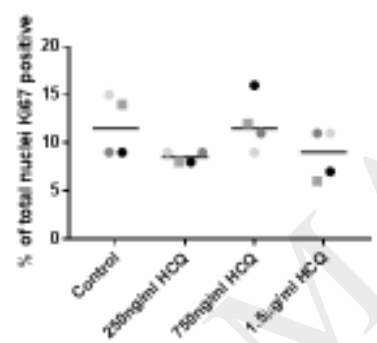

D.

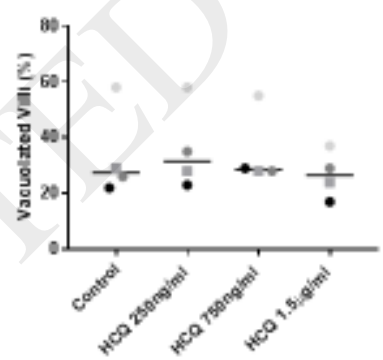

Figure 2: In the pilot study, $\mathrm{HCQ}(250 \mathrm{ng} / \mathrm{ml}-1.5 \mu \mathrm{g} / \mathrm{ml})$ did not affect A) apoptosis, B) proliferation,

C) integrity of the syncytiotrophoblast layer or D) number of vacuoles at any of the concentrations applied (Friedman test, $\mathrm{p}>0.05$ ). Each colour represents an explant culture experiment e.g. black = Explant Culture 1. Male fetuses are represented by a square point, whereas females are represented by circle. 


\section{Figure 3}
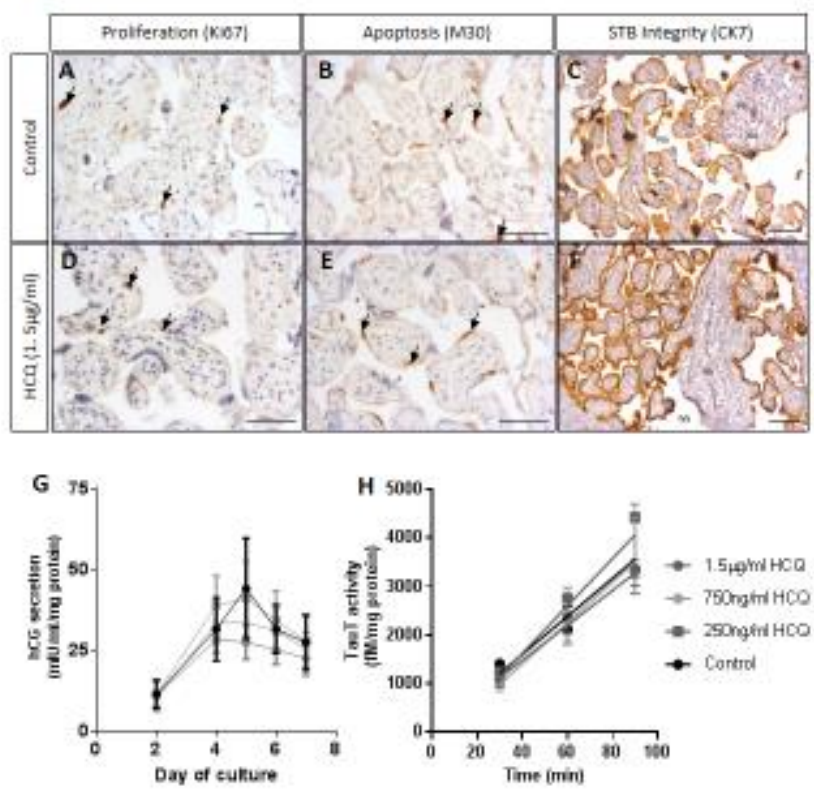

Note to the editor: Please print Figure 2A-F in colour. Thank you.

Figure 3: A-F) Examples of immunostaining for proliferation, apoptosis and syncytiotrophoblast (STB) integrity are shown for explants maintained in control conditions and medium with $1.5 \mu \mathrm{g} / \mathrm{ml}$ hydroxychloroquine (HCQ). Original magnification 200x with scale bar representing 50 $\mu$ m. Arrows indicate positive staining. STB = syncytiotrophoblast, IVS= intervillous space, VS = villous stroma, SV= stromal vacuole. G) Effect of $\mathrm{HCQ}$ on human chorionic gonadotropin (hCG) secretion by placental villous explants. hCG secretion increased from day 2-4 of explant culture before plateauing and decreasing on day 7. HCQ did not alter hCG secretion on day 2, 4 or 7 of explant culture (median and IQR, $n=4 ; p>0.05$, Friedman test). H) Taurine Transporter (TauT) activity in placental villous explants. TauT activity, measured as the Na-dependent uptake of ${ }^{3} \mathrm{H}$-taurine, increased linearly over time. Treatment with HCQ did not alter the rate of uptake $(p>0.05$, median and IQR, $n=4$, least squares linear regression). Male fetuses are represented by a square point, whereas females are represented by circle. 


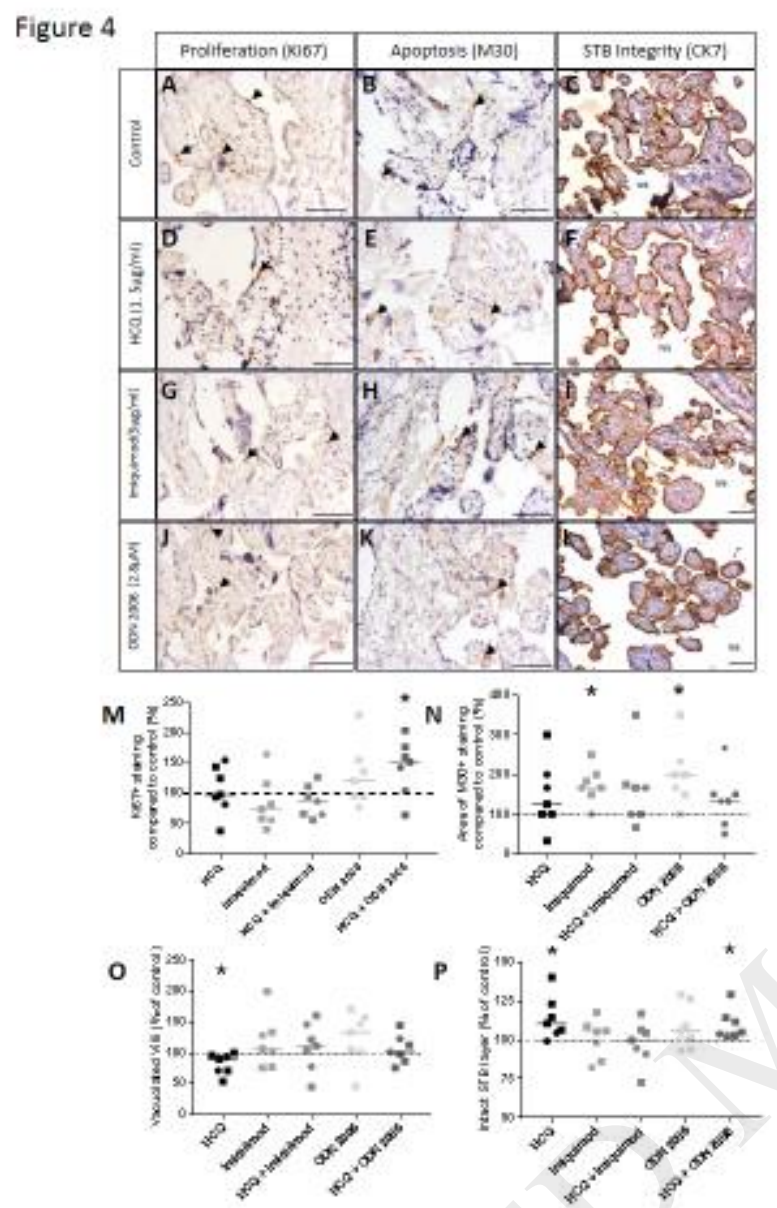

Note to the editor: Please print Figure 4A-L in colour. Thank you.

Figure 3: A-F) Examples of immunostaining for proliferation, apoptosis and syncytiotrophoblast (STB) integrity are shown for explants maintained in control conditions and medium with $1.5 \mu \mathrm{g} / \mathrm{ml}$ hydroxychloroquine (HCQ). Original magnification 200x with scale bar representing 50 $\mu$ m. Arrows indicate positive staining. STB = syncytiotrophoblast, IVS= intervillous space, VS = villous stroma, SV= stromal vacuole. G) Effect of $\mathrm{HCQ}$ on human chorionic gonadotropin (hCG) secretion by placental villous explants. hCG secretion increased from day 2-4 of explant culture before plateauing and decreasing on day 7. HCQ did not alter hCG secretion on day 2, 4 or 7 of explant culture (median and IQR, $n=4 ; p>0.05$, Friedman test). H) Taurine Transporter (TauT) activity in placental villous explants. TauT activity, measured as the Na-dependent uptake of ${ }^{3} \mathrm{H}$-taurine, increased linearly over time. Treatment with HCQ did not alter the rate of uptake $(p>0.05$, median and IQR, $n=4$, least squares linear regression). Male fetuses are represented by a square point, whereas females are represented by circle. 


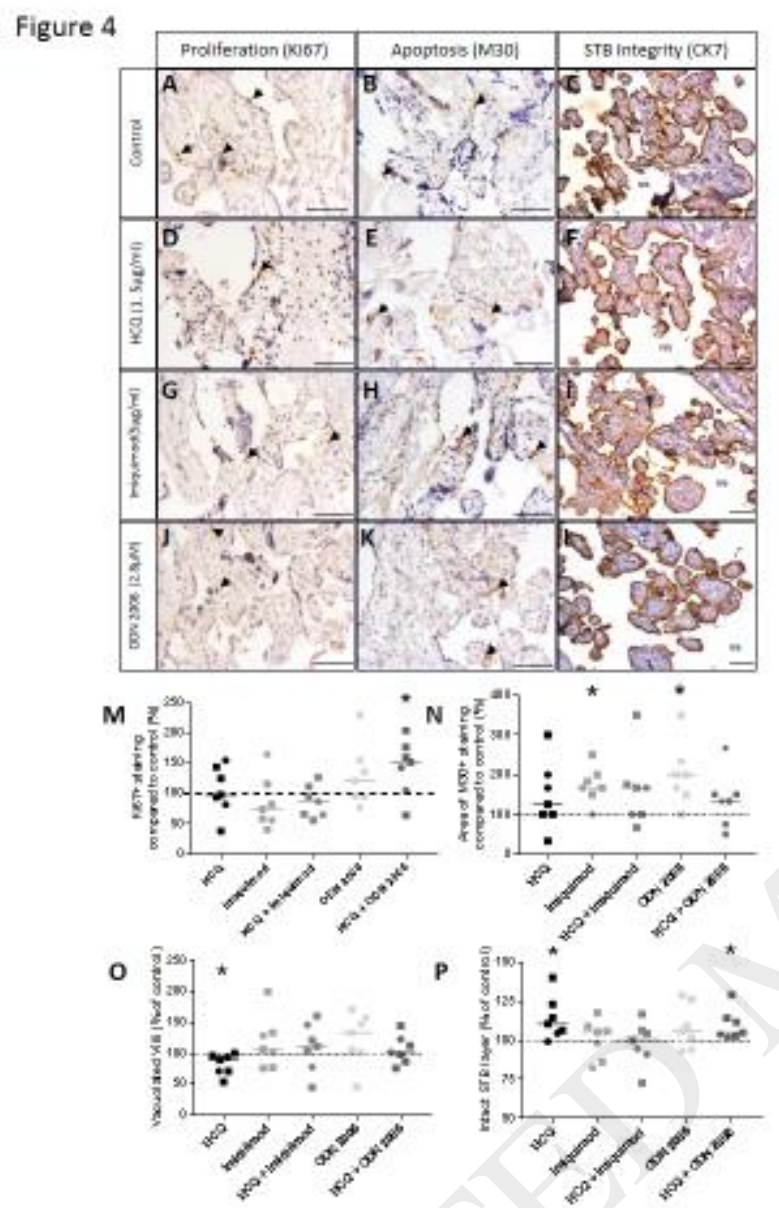

Note to the editor: Please print Figure 4A-L in colour. Thank you.

Figure 3: A-F) Examples of immunostaining for proliferation, apoptosis and syncytiotrophoblast (STB) integrity are shown for explants maintained in control conditions and medium with $1.5 \mu \mathrm{g} / \mathrm{ml}$ hydroxychloroquine (HCQ). Original magnification 200x with scale bar representing 50 $\mu$ m. Arrows indicate positive staining. STB = syncytiotrophoblast, IVS= intervillous space, VS = villous stroma, SV= stromal vacuole. G) Effect of HCQ on human chorionic gonadotropin (hCG) secretion by placental villous explants. hCG secretion increased from day 2-4 of explant culture before plateauing and decreasing on day 7. HCQ did not alter hCG secretion on day 2, 4 or 7 of explant culture (median and IQR, $n=4 ; p>0.05$, Friedman test). H) Taurine Transporter (TauT) activity in placental villous explants. TauT activity, measured as the Na-dependent uptake of ${ }^{3} \mathrm{H}$-taurine, increased linearly over time. 
Treatment with HCQ did not alter the rate of uptake $(p>0.05$, median and IQR, $n=4$, least squares linear regression). Male fetuses are represented by a square point, whereas females are represented by circle. 


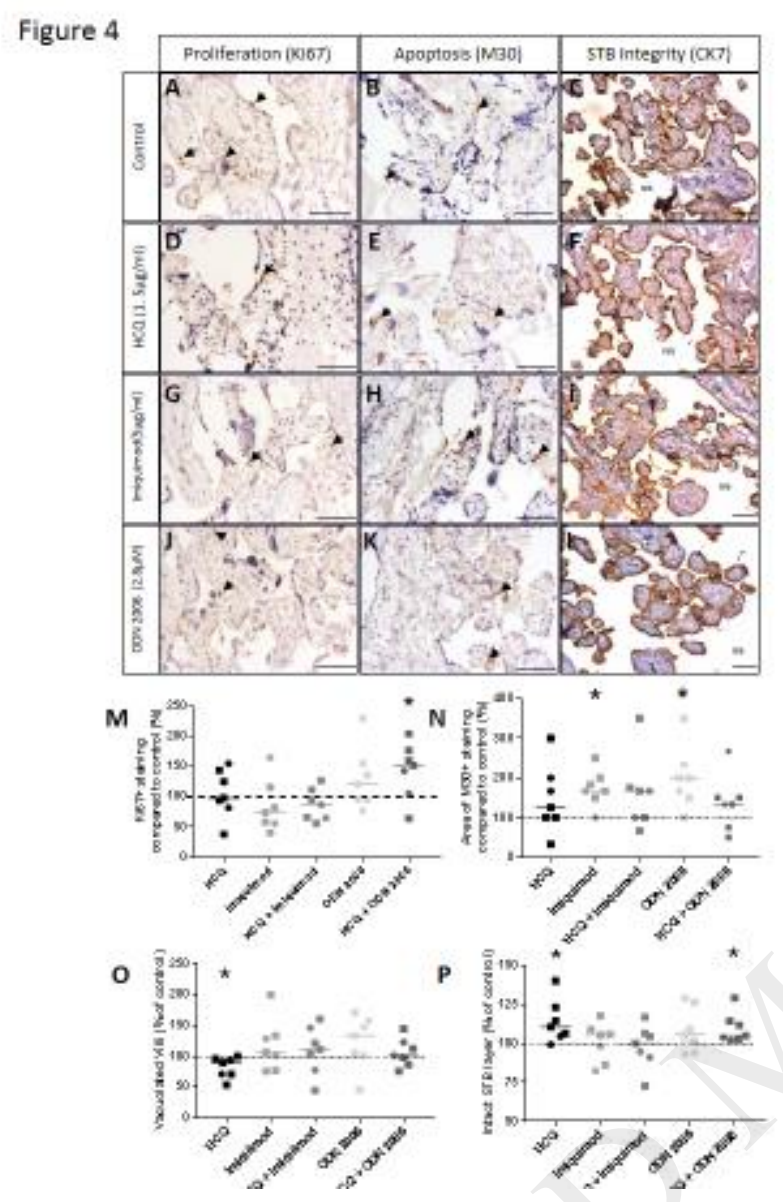

Note to the editor: Please print Figure 4A-L in colour. Thank you.

Figure 4: A-L) Examples of immunostaining for proliferation, apoptosis and syncytiotrophoblast (STB) integrity are shown for explants maintained in control medium, medium with $1.5 \mu \mathrm{g} / \mathrm{ml}$ hydroxychloroquine (HCQ), Imiquimod $(5 \mu \mathrm{g} / \mathrm{ml})$ and ODN $2006(2.8 \mu \mathrm{M})$. Original magnification 200x with scale bar representing $50 \mu \mathrm{m}$. Arrows indicate positive staining. STB = syncytiotrophoblast, IVS= intervillous space, $\mathrm{VS}=$ villous stroma, $\mathrm{SV}=$ stromal vacuole.

Effects of HCQ $(1.5 \mu \mathrm{g} / \mathrm{ml})$ and Toll Like Receptor agonists ODN $2006(2.8 \mu \mathrm{M})$ and Imiquimod $(5 \mu \mathrm{g} / \mathrm{ml})$ on: $\mathbf{M}$ ) proliferation (Ki67), $\mathbf{N}$ ): apoptosis (M30), O): stromal vacuoles (CK7) and P) STB integrity. Dotted line represents control group (normalized to $100 \%$ ). HCQ treatment reduced the number of stromal vacuoles and increased STB integrity. Imiquimod and ODN 2006 increased apoptosis, whilst 
HCQ + ODN 2006 increased proliferation and STB integrity. ( ${ }^{*} p<0.05 ; n=7$; Wilcoxon Signed Rank Test). Male fetuses are represented by a square point, whereas females are represented by circle. 


\section{Figure 5}

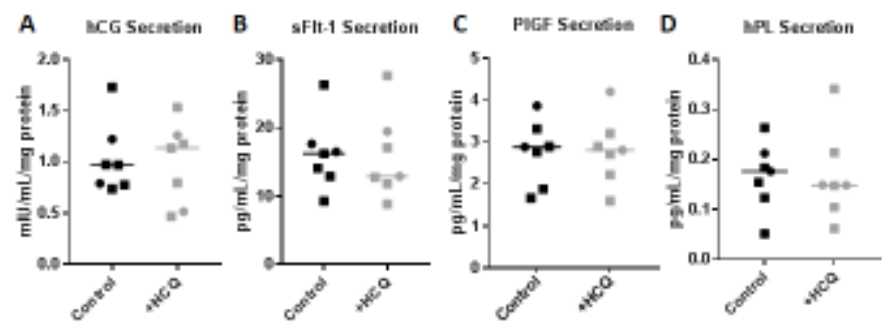

E

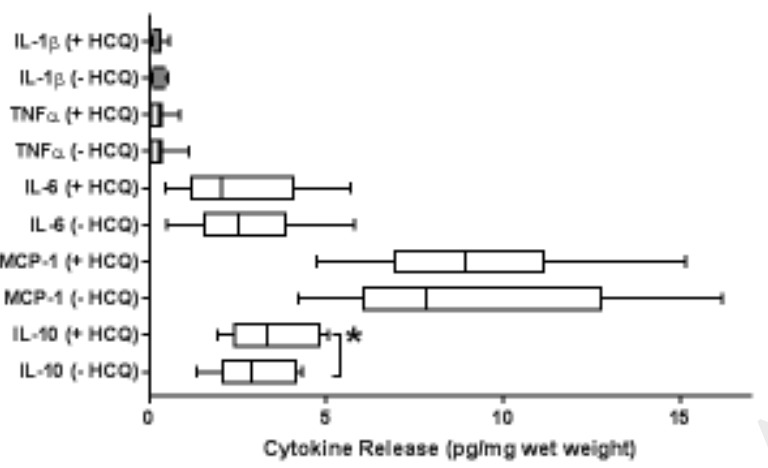

Figure 5. Effect of $24 \mathrm{hr}$ hydroxychloroquine $(\mathrm{HCQ})$ treatment $(1.5 \mu \mathrm{g} / \mathrm{ml})$ on endocrine and cytokine secretion in placental villous explants. Treatment with HCQ $(1.5 \mu \mathrm{g} / \mathrm{ml})$ for $24 \mathrm{hrs}$ did not alter release of: A) hCG, B) sFlt-1, C) PIGF or D) hPL, E) HCQ treatment increased IL-10 release compared to untreated groups $(p=0.016)$. HCQ treatment did not alter secretions of IL-1 $\beta, T N F \alpha$, IL-6 or MCP-1 ( $n=7$; two-tailed Wilcoxon test, $\left.{ }^{*} p>0.05\right)$. Placentas from male fetuses are represented by a square point, whereas females are represented by circle. 
Figure 6
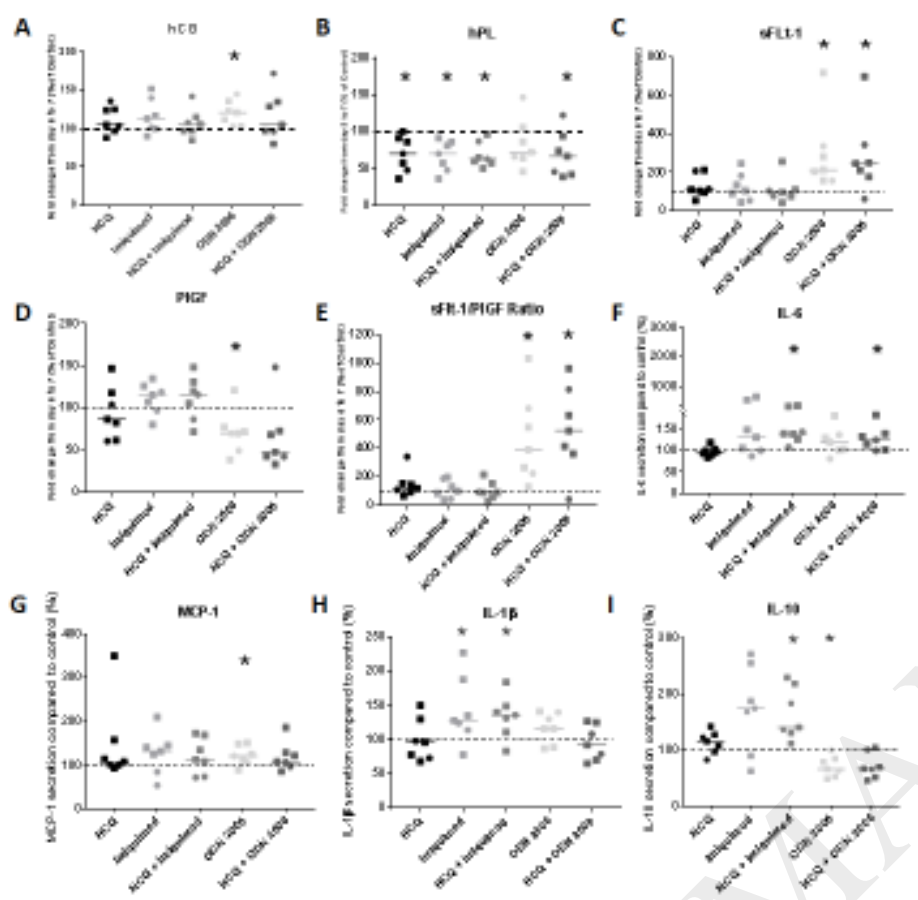

Figure 6. Effects of hydroxychloroquine (HCQ; $1.5 \mu \mathrm{g} / \mathrm{ml}$ ) and Toll Like Receptor agonists ODN 2006 $(2.8 \mu \mathrm{M})$ and Imiquimod $5 \mu \mathrm{g} / \mathrm{ml}$ ) on: A) hCG, B) hPL, C) sFlt-1, D) PIGF, E) sFlt-1/PIGF ratio, F) IL-6, G) MCP-1, H) IL-1 $\beta$ and I) IL-10. Dotted line represents control group (normalized to $100 \%)$. ( ${ }^{*} p<0.05$; $\mathrm{n}=7$; Wilcoxon Signed Rank Test). Male fetuses are represented by a square point, whereas females are represented by circle. A) ODN 2006 significantly increased hCG secretion compared to control $(p=0.016)$. B) Reductions in hPL release were seen following $H C Q$, Imiquimod, $H C Q+$ Imiquimod and HCQ + ODN 2006 treatments. C) ODN 2006 alone and in combination with HCQ increased sFLT-1 release $(p<0.050)$. ODN 2006 reduced PIGF release (D) and increased the sFLT-1/PIGF ratio (E). F) HCQ 
+ ODN 2006 increased release of IL-6. ODN 2006 increased release of MCP-1 (G) and IL-10 (I). HCQ + Imiquimod increased secretion if IL-6 (F), IL-1 $\beta$ (H) and IL-10 (I). 
